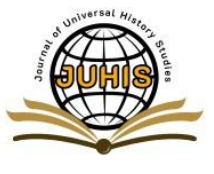

\title{
Bopal Nevvabı Sultan Cihan Begüm'ün İstanbul Ziyareti ve Osmanlı’ya Gönderdiği Yardımlar ${ }^{1}$ \\ Berna Korucu Üçüncü² \\ Inonu University, Research Assistant, Department of History, Malatya, Turkey \\ Received- Accepted: 10.10.2019-10.11.2019 \\ Research Article
}

$\ddot{O} \mathbf{z}$

Orta Hindistan'da yer alan ve Haydarabat Nizamlığı'ndan sonra en önemli devlet olan Bopal Nevvablı̆̆ı, dört kadın yöneticinin arka arkaya hüküm sürdüğü yıllarda, Hicaz ve İstanbul ile zaman zaman yakın münasebetler kurmuştur. Bu çalışmada, Bopal Nevvabı Sultan Cihan Begüm'ün Osmanlı Devleti'ne duyduğu yakınlık çerçevesinde onun İstanbul ziyareti, 1911-1912'de çıkan İstanbul yangınlarına ve Balkan Savaşları'na gönderdiği yardımlar, Osmanlı arşiv belgeleri, hatırat kitapları ve dönemin yerli-yabancı gazeteleri ışığında ele alınacaktır. Ayrıca Birinci Dünya Savaşı öncesi yaşanan bu sıcak gelişmelere rağmen, Sultan Cihan Begüm'ün bu savaşta neden İngiltere'nin yanında yer aldığı tartışılacaktır.

Anahtar Kelimeler: Hindistan, Osmanl1, Bopal, Bhopal, İstanbul.

\section{The Visit of the Nawab of Bhopal Sultan Jahan Begam to Istanbul and Her Aids to the Ottoman}

\begin{abstract}
Nawabs of Bhopal, which is the most important state after Nizam of Hyderabad in Central India, has established close relations with Hedjaz and Istanbul from time to time in the years when four women ruled in succession. In this study, it will be discussed that the visit of the Nawab of Bhopal Sultan Jahan Begam to Istanbul, within to the framework of proximity the Ottoman, her aids the Istanbul's fires and the Balkan Wars in 1911-1912 in consideration of Ottoman archival documents, memorial books and domestic-foreign newspapers. In addition, despite the friendly developments that took place before the First World War, it will be discussed why Sultan Cihan Begüm was on the side of England in this war.
\end{abstract}

Keywords: India, Ottoman, Bopal, Bhopal, Istanbul.

\footnotetext{
${ }^{1}$ This article is analyzed by two reviewers and it is screened for the resembalance rate by the editor. (Bu makale iki hakem tarafindan incelenmiş ve editör tarafindan benzerlik oranı taramasından geçirilmiştir)

${ }^{2}$ berna.ucuncu@inonu.edu.tr, ORDIC:0000-0001-7666-4119.
} 
Bopal Nevvabı Sultan Cihan Begüm'ün İstanbul Ziyareti ve Osmanlı'ya Gönderdiği Yardımlar/ Berna KORUCU ÜÇÜNCÜ

\section{Giriş}

XV. yüzyıldan itibaren birbirlerine uzak iki coğrafyada yer alan Osmanlı Devleti ile Hindistan'daki Müslüman devletler arasındaki ilişkiler genellikle halifelik ve hac meseleleri üzerine gelişmiştir. Sonraki yüzyıllarda Osmanlı Devleti'nin en güçlü Müslüman devlet olması, devletler arası ilişkilere yeni bir boyut getirmiştir. Çünkü 1707'de Babürlülerin son büyük hükümdarı Evrengzîb'in (Alemgir) ölmesiyle devlet eski gücünü kaybetmeye başlamıştı. Taht kavgaları sonucu yapılan savaşlarla birlikte devlete güçsüz yöneticiler hakim olmuş, siyasî birliğin bozulmasıyla ortaya pek çok küçük devlet çıkmıştı. Zamanla bu sultanlık ve racalıklar İngilizlerin hakimiyeti altına girmeye başladı. İngilizlere karşı zor durumda kalan sultanlıkların Osmanlı Devleti ile irtibat kurmak istedikleri görülmektedir. XVIII. yüzyılın sonlarına doğru Malabar ile Maysor Sultanlığı, İngiliz işgaline ve Hristiyan misyoner faaliyetlerine karşın Osmanlı Halifesi’nden yardım istemişlerdi. Ancak 1799'da Maysor Sultanı Tipu’nun ölmesi üzerine İngilizlere direnen son Müslüman devlet ortadan kalkmıştır. Böylece İngiliz hakimiyeti giderek hızlanmış ve 1857 Ayaklanması, Hindistan’ı İngiliz müstemlekesi durumuna getirmiştir(Özcan, 1997, s. 17-30).

İngiliz hakimiyeti altında da Müslüman devletlerin Osmanlı Sultanlan ile irtibat kurdukları anlaşılmaktadır. Bunlardan biri XVIII. yüzyılın başlarında, orta Hindistan'da kurulan ve Haydarabat Devleti'nden sonra en önemli Müslüman devlet olan Bopal (Bhopal) Nevvablığı'dır. ${ }^{3}$ Devletin kurucusu, Babürlü Alemgir'in hizmetine giren Afganlı Dost Muhammed Han'dır. Alemgir'in ölümünden sonra Hindistan'da görülen karmaşa üzerine Dost Muhammed Han, "Nevvab"4 unvanını alarak bağımsızlı̆̆ını ilan etmiştir (Öztuna, 2005, s. 944). 1778 yılında Bopal Nevvablığı ilk defa İngilizlerle münasebetlere girişmiş ve o dönemden sonra İngilizlerle birlikte hareket etmiştir (Konukçu, 1992, s. 283).

1819-1926 yılları arasında Bopal Nevvablığı'na arka arkaya dört kadın hakim olmuştur (Üçok, 1972, s. 446-450). ${ }^{5}$ Sirasiyla yönetime gelen Kudsiye Begüm, İskender Begüm, Şah Cihan Begüm ve Sultan Cihan Begüm zamanlarında, Osmanlı Devleti ile Bopal Nevvablığı arasındaki iyi ilişkiler kurulmuştur. Bu dört kadın hükümdarın ortak özelliklerinden biri Hicaz’a olan ilgileridir. Bopal yöneticileri her yıl Ramazan ayında Hicaz’a

\footnotetext{
${ }^{3}$ Yeni İkdam Gazetesi’nde yer alan habere göre, Cihan Begüm'ün İstanbul'a geldiği ertesi gün, Bopal hakknnda bilgi almak için tahrirat kaleminden biri görevlendirilmiş ve Pera Palas'ta Cihan Begüm'ün katibi olan Abdüssamed Han ile bir görüşsme yapılmıştr. Abdüssamed Han'ın ifadesine göre Cihan Begüm, Osmanlı Devleti’ni sever ve daima hürmet gösterirdi. Bu görüşmede Cihan Begüm, katibi vasitasılyla Osmanlı'yı, Meşrutiyet'i elde etmek için gösterdikleri şecaat ve metanet sebebiyle takdir etmektedir. Ayrıca Bopal hakknnda bilgi veren katip, bu tarihlerde Bopal'in 1.100.000 nüfuslu, 17.500 km alana sahip, yarı müstakil Müslüman küçük bir ülke olduğunu belirtmiştir (Yeni İkdam, 18 Temmuz 1327, s. 3): Bopal hakimesi Şah Cihan Begüm, Bopal tarihine dair bir eser için bkz. (Şah Cihan Begüm, 1876, s. 1); Ayrica Bopal Devleti haritast için bkz. Ek 1.

${ }^{4}$ Nevvâb, nâib kelimesinden türetilmiş, Urduca'da nevab, İngilizler ve Hindular tarafindan da nabob olarak telaffuz edilmiştir. Diğer Batı dillerine de bu şekilde geçmiştir. Nevvâb, Babürlü Devleti'nin idarî sisteminde siyasî makam ve güç ifade eden bir unvandır (Özcan, 2007, 67).

${ }^{5}$ Bopal Nevvabları doğunun en büyük kraliçeleri, yöneticileri arasında saylmaktadır (Layd Glover, 1927, s. 86).
} 

Kudsiye Begüm ve kendisinden sonra nevvab olacak Şah Cihan Begüm ile birlikte 1864 yılında hac ziyaretinde bulunmuştur (Sultan Cihan Begüm, 1918, s. 141; İskender Begüm, 1870, s. 148).

1868'de İskender Begüm'ün vefatı üzerine nevvab olan Şah Cihan Begüm ve eşi Sıddık Hasan Han, Osmanlı Devleti'nin genel durumunun bozulduğu ve Rus saldırıları ile devletin tehlikeye girdiği sıralarda, İslam'ın koruyucusu sayılan Türkler için maddî yardım toplatımıştır. ${ }^{7}$ Bu yardımlara karşılık, 1878 yılında Sıddık Hasan Bahadır Han'a ikinci dereceden “Mecidî Nişanı”, Şah Cihan Begüm'e de Mekke'de Hindistan haciları için tesisler yaptırdığı ve Bopal'i tren yolu hattına bağlayan demiryollarını inşa ettirdiği için "Şefkat Nişanı" verilmiştir (Özcan, 2010, s. 253). ${ }^{8}$ Ayrıca Haziran 1879'da Osmanlı Sadrazamı Hayreddin Paşa, Şeyh Mevlevî Muhammed Hüseyin vasıtasıyla Şah Cihan Begüm, Sıddık Hasan Han ve Bopal Devlet Başkanı Muhammed Cemaleddin'e ferman, hediyeler ve mektuplar göndermiştir. Şeyh Mevlevî Muhammed Hüseyin, Bopal'de büyük bir merasimle karşılanarak 25 pare top atışıla selamlanmıştır. Şah Cihan Begüm ile Sıddık Hasan, Mevlevî Muhammed adına verilen kabul töreninde II. Abdülhamid'den gelen nişanları takmıştır. Kabul töreninde Şah Cihan Begüm, II. Abdülhamid'in gönderdiği fermanı yüksek sesle okumuştur. Merasim sonunda Osmanlı Sultanı için dualar edilmiştir (Şerif'ül-Hasan, 1965, s. 20-21).

1901 yllında iktidara gelen Sultan Cihan Begüm, annesi Şah Cihan Begüm gibi Osmanlı Sultanı Abdülhamid'e yakınlık duymuş ${ }^{9}$, Padişaha olan bu bağlılı̆̆ından dolayı oğullarından birine Abdülhamid'e izafeten Hamidullah adını vermiştir (Öztuna, 2005, s. 946). 1903 yılında Sultan Cihan Begüm hac farizasını yerine getirmek için Hicaz'a gitmek istemişti (BOA, Y.A.HUS.. 460/129). Cihan Begüm’ün hac ziyareti, İngiliz ve Türk ilişkileri açısından önemlidir. Kafilenin Cidde’ye kadar güvenliği İngilizler tarafından sağlanmıştı. İngiliz komutan MacWatt burada bir konuşma yaparak Bopal Begümü’nün güvenliğini sağlamak için atılan her adımın İngiliz ve Türkler arasındaki dostça ilişkileri güçlendirmeye yardımcı olacağını söylemiştir (Sultan Cihan Begüm, 1913, s. 180-242) ${ }^{10}$

Medine'yi ziyaret eden Sultan Cihan Begüm, buradan Suriye kafilesine katılarak Mekke'ye gitmiştir (BOA, Y.A.HUS.. 459/79; BOA, BEO. 2267/169983). Zorlu bir yolculuktan sonra Mekke'ye ulaşan Sultan

\footnotetext{
${ }^{6}$ Begüm tarafindan gönderilen hediyelerin kabul edilmesi Cidde Valisi’ne bildirilmiştir (BOA, A.\}MKT.MVL. 75/33); İskender Begüm ve validesi Kudsiye Begüm 1000 adet riyali Osmanlı Padişahına takdim etmişlerdir (BOA, A.\}MKT.MHM.. 282/39).

${ }^{7}$ Şah Cihan Begüm 150.000, eşi Sıddık Hasan Han 25.000, kızı veliaht Sultan Cihan Begüm 9.000, diğer kızı Belkıs Cihan Begüm 500 İngiliz rupisi göndermiştir (BOA, HR.SYS.. 1234/70); Şah Cihan Begüm’ün biyografisinde Osmanlı askerlerine 100.000 rupi gönderildiği yazmaktadır (Sultan Cihan Begüm, 1926, s. 236); Siddık Hasan Han'ın Osmanlı Devleti ile ilişsileri için ayrıca bkz. (Eren-Yılmaz, 2002, s. 233-238).

${ }^{8}$ Ayrıca Sıddık Hasan Han'ın vasıflarıı ortaya koyan bir ferman gönderilmiştir (Sultan Cihan Begüm, 1926, s. 236); Şah Cihan Begüm'e II. Abdülhamid tarafindan gönderilen ferman, Şah Cihan Begüm'ün biyografisinin ekler kısmında yer almaktadır (Sultan Cihan Begüm, 1926, s. 299vd).

${ }^{9}$ II. Abdülhamid'e olan bu yakınlığı ile birlikte Sultan Cihan Begüm'ün yönetime geçer geçmez İstanbul'a ziyarette bulunduğuna ve yönetime geçişinde II. Abdülhamid'den müsaade aldığına dair kaynaklarda bilgiler geçmektedir (Uslu, 1993, s. 534). Ancak gerek Osmanlı Arşiv belgelerinde gerekse kendi kaleme aldığı hatıra kitaplarında böyle bir ziyarete dair bilgiye rastlanılmamıştır (Sultan Cihan Begüm, 1927, s. 148vd.); Şah Cihan Begüm ve kızı Sultan Cihan Begüm’ün resimleri için bkzEk 2.

${ }^{10}$ Cihan Begüm'ün Cidde'ye kadar güvenliği İngiliz komutan MacWatt tarafindan sağlanmış (BOA, Y.A.HUS.. 460/96), Cidde'den sonra Osmanlı askerleri kervanı koruma sorumluluğunu üstlenmiştir(BOA, HR.SFR.3.. 528/69).
} 
Bopal Nevvabı Sultan Cihan Begüm'ün İstanbul Ziyareti ve Osmanlı'ya Gönderdiği Yardımlar/ Berna KORUCU ÜÇÜNCÜ

Cihan Begüm'ü, Hicaz Valisi Ahmet Ratıb Paşa ve şehrin ileri gelenleri karşılamıştır (BOA, BEO. 2949/221151). Sultan Cihan Begüm'ün Kasım 1903 ylında başlayan ve Mart 1904 yılında tamamlanan hac ziyareti, yaklaşık beş ay kadar sürmüştür (Sultan Cihan Begüm, 1913, s. 338). Mekke ve Medine ziyareti esnasına Osmanlı misafirhanesinde kalan Sultan Cihan Begüm ülkesine döndügünde, II. Abdülhamid'e teşekkürlerini bildirmiştir. Sultan Cihan Begüm, Padişaha çok değerli hediyeler sunmuş, Mekke ve Medine'ye de para ve hediyeler göndermiştir (BOA, Y.A.HUS.. 472/54; BOA, Y.A.HUS.. 468/10).

Hac ziyaretinden sonra Sultan Cihan Begüm, Osmanlı Devleti’ne yakınlı̆̆ını, 1911 yılında İstanbul ziyareti, İstanbul yangınları ve Balkan Savaşları'nda maddî yardımlarda bulunarak göstermiştir. Ayrıca Müslüman kadınların eğitimi konusunda da kitaplar kaleme alan Cihan Begüm'ün görüşleri ve ülkesinde bu konudaki uğraşları Osmanlı'da yankı bulmuştur. Ancak Cihan Begüm'ün Osmanlı ve halifelik ile ilgili görüşlerinde zamanla bir kırılma yaşanmış ve Birinci Dünya Savaşı’nda Osmanlı’ya karşı İngilizlerden yana bir tavır sergilemiştir.

\section{İstanbul Ziyareti (1911)}

1911 yllında Avrupa seyahatine çıan Sultan Cihan Begüm'ün amacı, hasta olan oğlunu Avrupa'da tedavi ettirmek ve ülkesindeki Müslüman kadınların eğitimini arttırmaya yönelik yapacağı yenilikler için Avrupa'yı gözlemlemekti. Ona bu seyahatte, oğulları Ubeydullah Han ve Hamidullah Han, sekreteri Abdussamed Han, Hamidullah Han'ın özel sekreteri Vali Muhammed, gelini Şah Banu Begüm ve sekreteri eşlik etmiştir. Bopal'den Nisan ayında yola çıkan Cihan Begüm ve maiyeti, Mısır üzerinden Marsilya'ya gelmiştir. Buradan Paris'e geçen Cihan Begüm (Sultan Cihan Begüm, 1927, s. 136vd.), Temmuz ayında İngiltere'ye ulaşmıştır. İngiltere'de Kral V. George'un taç giyme törenine katılmıştır. Bir müddet burada kaldıktan sonra, Halife'yi ve en önemli İslam şehirlerinden olan İstanbul'u da ziyaret etmek istemiştir. 10 Temmuz 1911'de Cihan Begüm'ün İstanbul'u ziyaret edeceği, Hariciye Nazın Rıfat Paşa'ya bildirilmişti. (BOA, HR.TO.. 542/24; BOA, HR.SFR.3... 639/35). 18 Temmuz 1911'de Londra elçisi Tevfik Paşa, Cihan Begüm'ün İngiltere'den sonra Viyana'ya sonra da İstanbul'a gitmeyi planladığını haber vermiştir. Tevfik Paşa, 1 Ağustos’ta İstanbul'da olmayı umdukların ve onlar adına bir resepsiyon verilmesinin çok hoş olacağını da bildirmiştir (BOA, HR.SFR.3... 639/41).

15 Temmuz'da İngiltere'den ayrilan Cihan Begüm (The Observe, 16 July 1911, s. 6), bir hafta Cenevre'de kaldıktan sonra kalabalık maiyeti ve eşyasıyla birlikte 29 Temmuz günü saat 3'te İstanbul'a ekspresle gelmiştir. ${ }^{11}$ Cihan Begüm'ün maiyetinde 12'si kadın, 8'i erkek toplam 20 kişi vardı (Yeni İkdam, 17 Temmuz 1327, s. 2). Cihan Begüm'ü Hariciye Nazırı Rıfat Bey karşılamıştır. Pera Palas Otel'de konaklayan Sultan Cihan'1 ilk günlerde İngiliz büyükelçisi ve karısı ziyaret etti. Sadrazam Hakkı Paşa, Hariciye Nazırı Rıfat Paşa, Meclis-i

\footnotetext{
${ }^{11}$ Cihan Begüm ve maiyeti Cenevre'de alşveriş yaptktan sonra, 243 sandık yani iki kamyon dolusu eşya ile ayrılmıştı (The Evening News, 31 Ağustos 1911, s. 10; The Guardian, 1 Ağustos 1911, s. 7). Cihan Begüm'ün Cenevre'de yaptğı zengin alş̧veriş dönemin Avrupa basına yansımış̧r (Tuscaloosa News, 14 Ağustos 1911, s. 4; The Oregon Daily Journal, 13 Ağustos 1911, s. 47).
} 
Mebusan Reisi Ahmet Rıza Bey, Harbiye Nazırı Mahmud Şevket Paşa da Cihan Begüm'ü Pera Palas'da ziyaret edenler arasındadır (Şahbanu Begüm, 1914, s. 106). Sultan Cihan Begüm, ziyaretinin üçüncü gününde Tarabya'daki İngiliz Büyükelçisine konuk olmuştur. Daha sonra iki oğluyla birlikte Osmanlı padişahıyla görüşmek için Dolmabahçe Sarayı'na gitmişlerdir. Cihan Begüm hatıratında Sultan Reşad ile karşılaşmalarını şu şekilde anlatır:

"Ragıp Bey otele geldi, bana ve iki oğluma Dolmabahçe Sarayı'na kadar rehberlik etti. Girişte bizi ikinci bir resmi görevli karşıladı. Bize yol gösterdi, çok saylda koridoru geçerek muhteşem resepsiyon odasında bize kahve ve çay ikram edildi. Kısa bir aralıktan sonra üçüncü bir saray mensubu göründü ve Sultanın bizi beklediği bölüme aldı. Padişah selamladiktan sonra iki oğlum padişahın elini öptü. Sonra padişah bizi oturmaya davet etti. Kısa bir süre konuştuktan sonra, V. Mehmed Reşad, Valide Sultanı ziyaret etmek için Harem bölümüne giderken bana rehberlik etti. Tekrar sayısız koridorlardan geçtik. Sonunda iki uzun çizgide sıralanmış hadım korumaların görevli olduğu bölüme geldik. Onların arasından geçtikten sonra benzer diğer bir bölüme girdik. Burada hadımlar yerlerini kadın görevlilere birakt ve Sultan beni Harem'de kabul odasina götürdü. Çok beklemeden Valide Sultan geldi. Onu selamladım. Valide Sultan Türkçe konuştu, ben Farsça. Sultan tercüme etti. Padişah 'eğer örtünü çıkarırsan daha rahat konuşabileceksin, ben İngiliz büyükelçisi ve Sahibzadelerle kahve içeceğim' diyerek yanımızdan ayrldı. Bundan sonra ben örtümü çıkardım ve padişahın sekreterlerinden bir kaz tercüme için geldi. Valide Sultan'ın davranışları çok kibardı. Onu ziyaret etmemden memnunluk duyduğunu belirtti. Görüşmeden sonra Sultan'in kahyası Lütfi Bey, bize sarayı gezdirdi. 8 gün İstanbul'da kaldıktan sonra Boğaz kiyısındaki Tarabya'ya geçtik.' (Sultan Cihan Begüm, 1927, s. 149)

Sultan Cihan Begüm'ün V. Reşad'ı ziyareti, dönemin Mabeyn Başkatibi olan Halit Ziya Uşaklıgil tarafindan kayda değer görülmüştür:

"Gene şayan-ı kayd ziyaretlerden biri Hindistan'da nisbeten küçük bir kutanın melikesi olan Bübiya Bikûm'un Istanbul'a vürudu oldu. Behobal hâkimesi olan bu kadın kalabalık bir maiyetiyle Hamidullah, Ubeydullah isimlerindeki oğullartyla beraber Pera Palas'a nazil olmuş ve orada büyük bir daire işgal eylemişti. Müslüman olan bu Islamiyet'in en şedit kaidelerine mufrit bir mutabakatle merbut kalan bu kadın hakkanda hükümetçe ve sarayca icab eden ikram ve îzaz âsâr gösterilmekte tekâsül olunmadl. Hatta bu meyanda kendisine-İngilizceden başka bir garb lisanı bilmediği için- mihmandar olarak başkâtibin henüz genç olan kızı Bihîn tayin edildi. ${ }^{12}$ Ben melikeyi yakından görmedim. Onun yüzü daima en mütecessis gözlere karşı kalın bir perde geren peçesiyle kapalı imiş. Bu peçeyi hünkârın yanında kaldırmış olduğunu işittim, fakat hünkâra karşı istisnaî bir hareket olan yüzünü göstermek lûtfundan o sirada kendisine refakat eden İngiliz sefiri de istifade etmiş oluyordu. Huzurda oğulları da bulundu... Melike ile

\footnotetext{
${ }^{12}$ Bu kişi, Halid Ziya Uşaklıgil'in kızı Bihin Hatice'dir.
} 
Bopal Nevvabı Sultan Cihan Begüm'ün İstanbul Ziyareti ve Osmanlı'ya Gönderdiği Yardımlar/ Berna KORUCU ÜÇÜNCÜ

hünkâr nasıl konuştu. Arada bir tercüman olmayışına nazaran Hünkâr'ın Farisî söyleyebildiği kadar söylediğini, melikenin de Farisî anlayabildiği kadar anladığını farz ettik. Ingiliz sefirinin de hazır ve nazır olduğuna göre bu mükâlemenin üç beş havaî cümleden ibaret kalmuş olduğunda şüphe yoktur.” (H. Z. Uşaklıgil, 2012, s. 623-624)

Halit Ziya’nın Sultan Cihan Begüm'ün davranışlarına ve kültürüne dair verdiği bilgiler ve yaptığı yorum dikkat çekicidir:

"Melikenin hususî hayatına dair ufak tefek malûmatı mihmandarlarından almıştım: Maiyetinde hususî aşçısını beraber getirmişti. O Hint usulünde pişirdiği şeylerden başka bir şeye el sürmezmiş ve bu yemekler türlü baharat ile o kadar ağır şeylermiş ki mihmandar, kendisine ikram edilen bir yemekten büyük bir mide sancısı ile çımış. Bütün hizmetçiler yalinayak gezerlermiş. Uzak şark memleketlerinde bumun, hilâfina hareket edilemeyen bir usul olduğuna vâkaftı, fakat bir Avrupa seyahatinde aynı usulün tatbikinde usrar olunuşuna bir geri kalmak fikrine inad ile yapışıı olmaktan başka mânâ verilemezdi.” (H. Z. Uşaklıgil, 2012, s. 623-624)

Cihan Begüm'ün Türk yemeklerinden hoşlanmadığı, Ramazan'ın ilk günü Meclis-i Mebusan Reisi Ahmed Rıza Bey'in konağında verilen iftar yemeğinde görülmektedir (Yeni İkdam, 14 Ağustos 1327, s. 2). Ayrıca Halit Ziya'nın Cihan Begüm hakkındaki olumsuz görüşleri, Cihan Begüm’ün mihmandarlara verdiği hediyelerin tarifinden anlaşılmaktadır:

Melike'nin mihmandara hediyeleri oldu: Sert kokulu karanfillerle örülmüş, karmız ipek ve kılabdanla karıştırlmış bir örgü... Bu ne olacak, başa mi giyilecek, bunun istimalini anlamak mümkün olmadl. Sekiz on adet, pek iptidaî bir sanatla işlenmiş, gene ipek ve klabdanla karışı parçalar... Bunlar da belki bir sürahi, bir bardak, bir çiçeklik altına konabilir diye düşünüldü ve hiç bir zaman bu suretle istimaline teşebbüs edilemedi. (H. Z. Uşakligil, 2012, s. 623-624)

Sultan Cihan Begüm, İstanbul'dan çok etkilenmiş ve en güzel İslam şehirlerden biri olarak bahsetmiştir. Özellikle İstanbul'daki Kutsal Emanetler ilgisini çekmiş, onları görmek istemişti. Ancak bu kutsal emanetlerden Hz. Peygamber'in sakal-1 şerifi, hırka-i şerifi, ayak izi, Hz. Osman'ın elyazması Kur'an-1 Kerim'i, Hz. Ömer, Ebubekir, Osman ve Ali'ye ait kılıç ve İslam Sancağı, sadece yılda bir gün Ramazan'ın onbeşinde padişah tarafindan görüşe açılmakta ve sonra tekrar padişah tarafindan mühürlenmekteydi. Cihan Begüm her ne kadar bütün Kutsal Emanetleri göremese de Hz. Osman'ın kan izinin bulunduğu Kur'an-1 Kerim'e bakma firsatı bulmuştur. Ayrıca halife tarafindan her yl Mekke’ye gönderilen Kabe örtüsünü de görmüştür (Sultan Cihan Begüm, 1927, s. 150-151).

Sultan Cihan Begüm ve maiyeti Sultan Reşad ile görüştükten sonra Ahmet Rıza Bey'in eşliğinde Boğaz’ın Anadolu kıyısında inşa edilen kız okulunu görmeye gittiler. Cihan Begüm hala tamamlanmamış bu okulun planını çok beğendi. Burada Ahmet Rıza Bey'in iki kız kardeşiyle de tanıştı. Cihan Begüm'ün oğulları 
Hamidullah Han ve Ubeydullah Han askerî üniformalarıyla Mekteb-i Harbiye'yi ziyaret ettiler (Şahbanu Begüm, 1914, s. 107). ${ }^{13}$ İstanbul'daki Osmanlı mekteplerini ziyaret eden Ubeydullah Han, bu okulların çok iyi olduğunu ve temiz bulduğunu ifade etmiştir (Şahbanu Begüm, 1914, s. 114).

Ramazan aynın ilk günü Ragıp Raif, Begüm adına iftar yemeği düzenledi. Buna karşlık Begüm de Ragp Bey’in ailesine Pera Palas’ta çay ziyafeti verdi. Müzehaneyi ziyaret eden Begüm’e, Müze Müdürü Halil Bey tarafindan da hürmet gösterilmiştir (Yeni İkdam, 13 Ağustos 1327, s. 2). Ertesi gün Sadrazam Paşa vasitasıyla Cihan Begüm, Sultan Reşad'ın Ramazan-1 Şerifi'ni telgrafla tebrik etmiştir (Yeni İkdam, 14 Ağustos 1327, s. 2)

İstanbul'dan ayrilmadan önce padişah, Hz. Peygamber'in saç telini Cihan Begüm'e bağışlamıştır. Cihan Begüm bundan çok mutlu olduğunu ve kendisine hediye olarak Hz. Peygamber'in mezarından bir örtü ve I. Mahmud tarafindan kullanılan tarihî bir ayna verildiğini söylemektedir. Cihan Begüm ve maiyeti Ramazan ayını İstanbul'da geçirmeyi, sonrasında Kudüs'e gitmeye niyet etmişti. Ancak bu dönem Kudüs ziyareti için pek uygun değildi. Planlarını değiştirerek İstanbul'da kalmak yerine Budapeşte'ye gitmişlerdir (Sultan Cihan Begüm, 1927, s. 151; Preckel, 2000, s. 191). Cihan Begüm ve maiyeti 27 Ağustos akşamı ekspresle İstanbul'dan ayrilmıştır (Yeni İkdam, 15 Ağustos 1327, s. 2). Budapeşte'den Venedik'e oradan Floransa ve Brindisi'ye gitmişler, Port Sait üzerinden Bopal'e geri dönmüşlerdir (Şahbanu Begüm, 1914, s. 120vd.).

\section{İstanbul Yangınlan ve Balkan Savaşlarına Yardımlanı}

Hindistan Müslümanlarının Osmanlı Devleti’ne olan ilgi ve alakaları Kırım Savaşı'ndaki destekleriyle ilk defa kendini göstermişti. 1857'de Hindistan'da İngilizlerin Babürlüleri fiilen ve hukuken ortadan kaldırmaları, Hindistan Müslümanlarının tek bağımsız Müslüman devlet olan Osmanlı Devleti’ne desteklerini artırmıştır. 1875'deki Balkan olayları Osmanlı Hilafeti'nin, Hindistan Müslümanları üzerindeki nüfuzunu net bir şekilde ortaya çıkarmıştır (Eraslan, 1992, s. 113). Hindistan Müslümanları, 1877-1878 Osmanlı-Rus Savaşı'nda ise bütün güçleriyle Osmanlı Devleti'ni desteklemiştir. Osmanlı Devleti'ni içinde bulunduğu kötü durumdan kurtulmasına yardım etmek için birçok yerde iane sandıkları açarak yardım toplamışlar, bildiriler ve dilekçeler hazırlayarak İngilizleri Osmanlı Devleti’ne destek olmaya çağırmışlardır. ${ }^{14}$

Sultan Cihan Begüm de Osmanlı Halifesi’ne bağlıı̆ını her firsatta gönderdiği yardımlarla göstermiştir. İstanbul ziyaretinde bulunmadan önce Cenevre'deyken İstanbul'da büyük bir yangın çıktı̆ı̆ı duymuş ve bu habere çok üzülmüştür. Kayıtlara "Uzunçarşı Yangını” olarak geçen bu yangın, 23 Temmuz 1911'da başlamıştır. Bu yangın İstanbul'da çıkan en büyük yangınlardan biridir. Uzunçarşı'da Beyaz Cedid Mahallesi'nde çıkmış, hızla etrafa yayılmıştır. Yangında tahminen 2224 hane, 10-15 firın olmak üzere 300'den fazla dükkan ve bir çok mescitten başka on altı cami, iki medrese ve iki resmi daire, iki karakol, iki hamam, birkaç tekke ve türbeyle bir

\footnotetext{
${ }^{13}$ Habibullah ve Hamidullah Han'ın Mekteb-i Harbiye'yi ziyaretleri esnasında çekilen fotoğraf için bkz. Ek 4.

${ }^{14}$ Hindistan Müslümanlarının Osmanlı Devleti’ne gönderdiği maddî yardımların gerçek rakamı tespit etmek güç olmakla birlikte resmi Osmanlı vesikaları 124.843 Osmanlı lirasının İstanbul'a ulaşı̆̆ını göstermektedir ki, bu rakam 10.000.000 Hindistan rupisinin üstündedir. Bu yardım bütün İslam dünyası içinde en fazla meblağı oluşturuyordu (Çetinsaya, 1988, s. 36).
} 
Bopal Nevvabı Sultan Cihan Begüm'ün İstanbul Ziyareti ve Osmanlı'ya Gönderdiği Yardımlar/ Berna KORUCU ÜÇÜNCÜ

ahır yanmıştır (Cezar, 1963, s. 378-379).

Yangın haberini alan Cihan Begüm, yangından zarar görenler için 5.000 İngiliz sterlini göndermiştir (The Times, 07.08.1911). ${ }^{15}$ Cihan Begüm'ün oğulları Habibullah Han 150 pound ve Hamidullah Han 100 pound miktarında bağışta bulunmuştur. Cihan Begüm'ün gelini Şahbanu Begüm, İstanbul ziyareti esnasında hediye edilen Sakal-1 Şerif'in, Sultan Cihan Begüm'e bu yardımı karşılığında verildiğini ifade etmektedir (Şahbanu Begüm, 1914, s. 117).

İstanbul'da 3 Haziran 1912'de Sultanahmet ve Ayasofya taraflarında başka bir yangın çıkmıştı. 'İshak Paşa Yangını" diye anılan bu yangında 885 bina yok olmuştur. Sultanahmet ve Ayasofya tarafindaki bu yangın İstanbul'un güzel evlerinin bulunduğu bir mıntıkayı harap etmiştir (Cezar, 1963, s. 379). Ülkesine döndükten sonra bu yangın haberini alan Cihan Begüm, İshak Paşa Yangını'ndan dolayı Osmanlı Devleti'ne yardım göndermiştir. Ancak Cihan Begüm, Bağdat'a Sultanahmet yangını için gönderdiği para İstanbul'a ulaşmamıştır. İadesi mümkün olmadığından bu meblağ Donanma-yı Osmanî Cemiyetine teslim edilmiştir (BOA, DH.EUM.THR. 80/66). ${ }^{16}$

Trablusgarb ve Balkan Savaşlan'nda Hindistan Müslümanları, savaş esnasında Hindistan'ın pek çok şehrinde Osmanlı Devleti'ni desteklemek için mitingler ve toplantılar düzenlemiş, yardım kampanyalan başlatmıştır. Osmanlı Devleti’ne yardımlar gönderilmiştir. Hindistan'dan bu dönemde gönderilen yardımların miktarını tam olarak tespit etmek mümkün değilse de Osmanlı Hilâl-i Ahmer Cemiyeti’nin yayınlamış olduğu salnameye göre 1913 yllı itibaryyla dünya Müslümanları tarafindan gönderilen 263 bin liranın 158 bin 44 lirasını Hindistan'dan gönderilen yardımlar oluşturmaktadır (Tellioğlu, 2015, s. 795vd.).

Balkan Savaşlarında Sultan Cihan Begüm, muhtaçlar için Osmanlı Kızlayı'na 21.000 rupi göndermiştir. Aynı zamanda Bopal'de bir fon açarak devlet gazetesinde yayınlanmasını sağlamış ve bir ay gibi kısa zamanda 30.000 rupi toplanmışır (Sultan Cihan Begüm, 1927, s. 235). Kızılay kayıtlarına göre 1912 yılında Sultan Cihan Begüm, 154.681, 184.857, 65.900 kuruş/para nakdî yardımda bulunmuştur (İzgöer, 2015, s. 110, 111, 115). ${ }^{17}$ Cihan Begüm'e gönderdiği yardımlardan dolayı hükümet adına teşekkür beyanı gönderilmiştir (BOA, HR.SYS. 2019/4). Cihan Begüm Balkan Savaşlanı'nda yaptığı nakdî yardımlarla birlikte, yaralı askerlere yardım için kendi doktorlarından Muhammet Nuzzârulhak Legan'1 da göndermiştir. Doktora yaptığı hizmetlerden dolayı dördüncü rütbeden Mecidî Nişanı ve gümüş Hilâl-i Ahmer madalyası verilmiştir (BOA, MV. 234/170).

\footnotetext{
${ }_{15}^{15}$ Yardım miktarı Osmanlı basınnnda 6.000 İngiliz sterlinidir (Sebîlürreşâd, 17 Temmuz 1329, s. 364).

${ }^{16}$ Toplam yardım miktarı olarak 2610,5 kuruşsur (BOA, DH. EUM. THR. 78/30): 2500 İngiliz lirası içeren 2 kita çek İngiliz Sefareti aracllı̆̆yla göndermiștir (BOA, BEO. 4072/3053499).

${ }^{17}$ Bopal'den bu savaşlar için gönderilen yardım miktarları için bkz. (BOA, İ..MBH. 11/104; BEO. 4159/311859; BOA, BEO. 4163/312188,4083/306224; BOA, İ.MBH. 11/95)
} 


\section{Sultan Cihan Begüm'ün Osmanlı Kadınları ve Hilafet Hakkındaki Görüssleri}

Sultan Cihan Begüm ülkesinde, özellikle kadınlar için sosyal ve eğitim reformlarını desteklemiştir. ${ }^{18}$ Köy köy gezerek kadınların sorunlarını dinlemiş, kadınların ve çocukların sağlığı için hastaneler kurmuştur. Yetim kızlara hemşirelik ve ebelik eğitimi aldırmış, hemşirelik okulu kurmuştur. Cihan Begüm, Hindistan'daki Müslüman kadınları hem akademik hem de pratik olarak eğitmek istiyordu. $\mathrm{O}$, kadınların kurtuluşunun ancak eğitim yoluyla olduğunu düşünüyordu. Kadın eğitimini teşvik etmek için, eğitim firsatına dikkat çekmiş ve Kuran-1 Kerim'de eğitimin hem erkek hem de kadınlar için zorunlu olduğunu yazmıştır (Islam, 2014, s. 47-52). Cihan Begüm'ün Müslüman kadınların eğitimi konusundaki bu görüşleri dönemin Osmanlı basınında tercüme edilerek yayınlanmıştır. ${ }^{19}$

Cihan Begüm'ün Müslüman kadınlar için Hindistan'da yaptığı icraatlar Osmanlı'da da yankı bulmuştur. S. M. Tevfik tarafindan kaleme alınan yazıda, Cihan Begüm'ün ilim ve faziletlerinden söz edilmektedir. Ayrıca eğitim uğruna çok fazla para harcayan Cihan Begüm'ün insanlık ve iyiliği, sadece Hindistan'a özgü olmayıp, Afrika'ya, Mısır'a, İstanbul'a, İran'a ve bütün Müslüman ülkelere sirayet etmiştir. Cihan Begüm, Hindistanlı kadınların cehalet ve eğitimsizliğine bakarak, bu illetlerden kurtulmalan için Hindistan'da kız çocuklarına özel okullar açmıştır. ${ }^{20}$

Cihan Begüm yazdığı eserlerde, o dönem Osmanlı aydınlarının da tartıştıkları "Battlılaşma" meselesiyle ilgili görüşler belirtmiştir. Ona göre, Batının iyi tarafları alınarak, kötï tarafları terkedilmelidir. Bununla birlikte eserlerinde Cihan Begüm Osmanlı kadınlarını giyim kuşam yönünden eleştirmektedir. Cihan Begüm Müslüman kadınların iki problemi olduğunu söyler. Bunlar peçe ve eğitimdir. ${ }^{21}$ İstanbul'a geldiğinde de bu konularda gözlemlerde bulunmuştur. Cihan Begüm, Hindistan'da Müslüman kadınların kendilerine Türk kadınlarını örnek almamalanı gerektiğini de söylemektedir. Çünkü "Türk kadınları Avrupalı komşuların benimsemiștir. Sadece eğitimle ilgilenmemişler, stnırsız özgürlüğün zararlarını, İslam'in emirlerini terk ederek onurlarını kirletmişlerdir." demektedir(Hurley, 1998b, s. 270).

Gelini Şah Banu Begüm de bazı Türk kadınlarının Avrupalı tarzda giyindiklerini ve yaşam tarzlarının onlara benzediğini ifade eder. Ona göre, Türk kadınları her ne kadar dindar görünse de “özgürlük” fikri aralarında giderek artmaktadır. Peçe kullanımı ise gittikçe azalmaktadır (Şahbanu Begüm, 1914, s. 114).

Cihan Begüm'ün Türk kadınlanyla ilgili olumsuz görüşleri İstanbul'la ilgili izlenimlerine de yansımıştır. Cihan Begüm İstanbul ziyareti sonrası görüşleri, kendi eserlerinden ziyade onunla birlikte seyahat

\footnotetext{
${ }^{18}$ Bu Hintli Müslüman kadın politikacılar sosyal reformcudur (Hurley, 1998a, s.68vd).

19 “Terbiye-i Nisvan-ı İslam Hakkanda Bhopal Hakime-i Zişanı Sultan Cihan Hazretlerinin Mühim Bir Mektupları” başlığında yayınlanan bu mektup, Cihan Begüm'ün, Allahabad İnas Mektebi müdiresine yazdığı mektubun tercümesidir (Sebîlürreşâd, 27 Şubat 1329, s. 7-9).

${ }^{20}$ Aligarh şehrinde inşa edilen bu okulun resmi açılışına katılan Cihan Begüm, yaptığ konuşmada eğitimin önemine işaret etmiştir. Bu konuşma, "Bhopal Hakime-i Zişanı Şah Cihan Hazretleri'nin Hindistan'da Esasat-ı İslamiyye Dairesinde Kız Mektepleri Küşsadı” başlığıyla yayınlanmıştır. Cihan Begüm'ün konuşması o kadar etkili olmuştur ki, sonraları birkaç kişi Hindistan'ın bazı yerlerinde bu gibi müesseseler kurmuştur (Sebîlürreşâd, 17 Temmuz 1329, s. 364-365).

${ }^{21}$ Sultan Cihan Begüm'ün Müslüman kadının neden örtünmesi gerektiğiyle ilgili görüşleri için bkz. (Sultan Cihan Begüm, 1922, s. 112).
} 
Bopal Nevvabı Sultan Cihan Begüm'ün İstanbul Ziyareti ve Osmanlı'ya Gönderdiği Yardımlar/ Berna KORUCU $\underline{\text { ÜÇÜNCÜ }}$

eden gelininin kaleme aldığı hatırattan anlaşılmaktadır. ${ }^{22}$ Cihan Begüm, Türkler'in daha Avrupa'nın çok gerisinde olduklarını, öğrenecek ve yapacakları çok şeyin bulunduğunu belirtir. Ayrıca İslam dünyasındaki sıkıntıların sebepleri üzerine de düşünen Cihan Begüm, bu sıkıntıların daha çok ulemanın tavrından kaynaklandığını ileri sürmektedir;

"Bu din bilginlerinin çoğu peygamberin sahip olduğu iyi davranı̧lardan daha fazla ön yargıya sahipler. Bu din adamları dünyevi şeylerle uğraştılar. Bu tür bir dini lider muhtemelen insanlar üzerinde kötü bir etkiye sahiptir. Bu Müslümanların ahlaki ve milli bozulmaların önemli ölçüde açıklar. 'Sizler kitabı okuduğunuz halde insanlara iyiliği emredip kendinizi unutuyor musunuz? Aklınız kullanmıyor musunuz?' (Bakara-44). Ulemamızın işleri basitleştirmek yerine daha karmaşık hale getirmekten gurur duyduğu için üzülmek gerekir.” (Şahbanu Begüm, 1914, s. 118vd.) demektedir.

Cihan Begüm'ün İstanbul ziyareti, TBMM'nin gündemine halifelik ve laiklik tartışmalarının yapıldığı bir esnada gelmiştir. 13 Kasım 1920'de TBMM'de yapılan görüşmede Antalya milletvekili Rasih Efendi, hükümet şekli ve hilafet tartışmalarının ${ }^{23}$ olduğu esnada, Viyana'dayken bir gazeteye verdiği demece dayanarak, Sultan Cihan Begüm’ün İngilizler tarafindan, İslam dünyasını Osmanlı Türklerinden soğutmak için gönderildiğini söylemiştir; "Orayı da nazarı itibara alını ki o hâkimler, hep İngilizler tarafindan propaganda yapmak için Istanbul'da gördüklerini Viyana'da söylemek için İstanbul'a gönderilmiş adamlardl. Âlemi islâmı bizden ve islâmiyetten soğutmak için gönderdiği adamlardı." Rasih Efendi’ye, Aydın Milletvekili Tahsin Bey “ $O$ kadın bunu kabul etmez, ben onu biliyorum iftira ediyorsun" (TBMM, Z. C., s. 128) diyerek karşı çıkmıştır.

Sultan Cihan Begüm'ün Osmanlı ve halifelik konusundaki fikrî değişikliğinin, XIX. yüzyılın sonlarında Hindistan' da ortaya çıkan bazı gelişmelerden kaynaklanabileceğini söylemek mümkündür. Bu yıllarda Hindistan Müslümanları arasında iki farklı görüş ortaya çıkmıştı. Bunlardan ilki “Deoband Ekolü” diğeri ise “Aligarh Ekolü’ idi. Deoband Ekolü İngilizlerin aleyhine faaliyetlerde bulunurken, Aligarh Ekolü İngilizlerden yana bir politika geliştirmişti. Aligarh Ekolü’ne göre halifelik kurumu sadece Osmanlı halifesine ait değildi, Osmanlı halifesi sadece Osmanlı topraklarındaki Müslümanların lideriydi, o sebeple eğer İngilizlerle Osmanlı Devleti arasında bir savaş çıkarsa Hintli Müslümanlar İngilizlerden yana olmalıydı (Öke, 2005, s. 22vd ). Bu görüş, I. Dünya Savaşı'nın çıkmasıyla fiiliyata geçti. Hindistan'da İngilizlere tabi Müslüman devletler bu savaşta onlardan yana bir tavir sergilediler (Hurley, 2003, s. 172).

\footnotetext{
${ }^{22}$ Eser, "Siyahat-i Sultani” adıyla Arapça kaleme alınmıştır (Sultan Cihan Begüm, 1927, s. 136).

${ }^{23}$ Meclisteki hilafet tartışmaları, 'Hükümet hilafeti kapsar ise Kuran’a karşı hükümet kanunu olamaz. Olur ise Müslüman diğer ülkeler sizi ciddiye almaz öncü olamazsınız”, fikri üzerineydi (TBMM, Z C., 13.09.1336, İ. 64, C. 3, s. 128).
} 
Sultan Cihan Begüm Aligarh Üniversitesi’nin ${ }^{24}$ kurucuları arasında olduğu için bu ekolle aynı görüşte olduğu düşünülebilir. Sultan Cihan Begüm, Birinci Dünya Savaşı öncesi Osmanlı halifesine her türü destekte bulunmuştu. Ancak bu savaşta İngilizlerden yana, Osmanlı halifelisinin karşısında yer almıştır. Cihan Begüm, İtilaf Devletleri için cephane, yiyecek ve para bağışlamıştır. İngiliz ordusuna katılmak üzere bir bölük göndermiştir (Uslu, 1993, s. 534). Ayrıca Sultan Cihan Begüm'e göre Osmanlı'da halifelik küçük bir Türk grubun, Jön Türklerin elindedir. Onlar ise İslam için hiçbir şey yapmamıştır (Hurley, 1998b, s. 269). Bütün bu gelişmeler, İstanbul ziyareti sonrası Sultan Cihan Begüm’ün Osmanlı Devleti’ne ve halifeliğe olan görüşlerinde büyük bir değişiklik yaşadığını göstermektedir.

\section{Sonuç}

Hindistan'da önemli Müslüman devletlerden biri olan Bopal Nevvablığı ile Osmanlı arasındaki ilişkiler daha çok Hicaz ve hilafet üzerinden gerçekleşmiştir. 1901 ile 1926 yılları arasında yönetimde olan Sultan Cihan Begüm, halefleri gibi İslam dünyasının lideri olan Osmanlı Sultanına karşı büyük bir bağlılık duymuş ve 1903 yılında hac farizasını yerine getirdikten sonra, 1911 ylında İslam dünyasının merkezi olan İstanbul'u ziyaret etmek istemiştir. Temmuz ayının sonunda İstanbul'a gelen Cihan Begüm, Sultan Reşad ile Valide Sultan'1 ziyaret etmiş, bazı Kutsal Emanetleri görme firsatı bulmuşsur. Hatta kendisine İstanbul yangınlarına yaptığı yardımlardan dolayı Hz. Peygamber'in Sakal-1 Şerifi bağışlanmıştır. Aynıca Hz. Peygamber'in mezarından bir örtü ve I. Mahmud tarafindan kullanılan tarihî bir ayna da hediye edilmiştir.

İstanbul'da yaklaşık bir ay kalan Cihan Begüm ve maiyeti, ziyareti süresince önemli ve tarihi yerleri görmüş̧ür. Cihan Begüm, Boğaz'ın Anadolu kıyısında inşa edilen kız okulunu, oğulları ise Mekteb-i Harbiye'yi ziyaret etmişlerdir. Aynca devlet erkanı tarafindan düzenlenen davetlere katılmışlardır. Buna karşılık Pera Palas'ta da Cihan Begüm çay ziyafetleri düzenlemiştir. İstanbul'u çok güzel bulmasına rağmen Cihan Begüm, Türklerin Avrupa'nın çok gerisinde olduğunu gözlemlerinde belirtmiştir. Cihan Begüm’ün Türkler hakkında bu olumsuz görüşlerine karşılık Sultan Reşad ile görüşmesine şahitlik eden Halit Ziya da onlar hakkında benzer olumsuz düşüncelere sahiptir. Cihan Begüm ve maiyetinin davranışlarını yadırgamakta ve verilen hediyelere dayanarak onları küçümsemektedir. Bu durum, iki farklı kültürün karşılıklı nasıl algılandığı noktasında kayda değerdir. Cihan Begüm'ün Türkleri Avrupa'nın gerisinde görmüş, buna karşllk Halit Ziya'da Avrupa görmüş bir kişinin davranışlarını ilkel bulmuştur.

İstanbul ile ilgili haberleri yakından takip eden Cihan Begüm, 1911-1912'de Uzunçarşı ve İshak Paşa Yangınlarından dolayı çok üzülerek bu felaketlerden etkilenen Müslümanlar için yardım göndermiştir. Trablusgarp ve Balkan Savaşları'nda da Osmanlı Devleti'ne destek veren Hindistanlı Müslümanlar arasındadır. Balkan Savaşları'nda yaptığı nakdî yardımlarla birlikte, yaralı askerlere yardım için kendi doktorlarından birini de Osmanlı'ya göndermiştir.

\footnotetext{
${ }^{24}$ Cihan Begüm, bu kolejin kurulmasında büyük bir meblağ harcamış, ayrıca senelik bir tahsisat da bağışlamıştır (Sebîlürreşâd, 17 Temmuz 1329, s. 364). Ayrıca Cihan Begüm, eğitim faaliyetlerinden dolayı Aligarh Üniversitesi’nin idari kademesine seçilen tek kadındı (Uslu, 1993, s. 535).
} 
Bopal Nevvabı Sultan Cihan Begüm'ün İstanbul Ziyareti ve Osmanlı'ya Gönderdiği Yardımlar/ Berna KORUCU ÜÇÜNCÜ

Cihan Begüm, kaleme aldığı yazılarında Hilafet ve İslam dünyasının meselelerine dair görüşler beyan etmiştir. İslam dünyasının içinde bulunduğu durumdan İslam alimlerini sorumlu tutmuştur. Aynca Osmanlı aydınlarının tartışı̆̆ı "Batılılaşma" konusunda da fikir beyan etmiştir. Ona göre Batı sadece teknik yönden taklit edilmelidir. Aynıca Osmanlı kadınlarını giyim kuşam yönünden eleştirerek, onların örnek alınmaması gerektiğini de savunur. Ona göre Türk kadınları Avrupalılara benzemektedir. Cihan Begüm, Türkler ve Türk kadınları hakkındaki görüşleri bu noktada birbirine tezat görünmektedir. Bununla birlikte Cihan Begüm'ün insanlığı ve iyiliği, Müslüman kadınların eğitimi ilgili görüşleri ve ülkesinde bu konuda yaptığı işler Osmanlı' da yankı bulmuş ve övgüye değer görülmüştür.

İki ülke arasındaki yakın ve samimi ilişkiler Birinci Dünya Savaşı’na kadar sürmüştür. Bu savaş başladığında Cihan Begüm İngilizlerden yana bir politika takip etmek durumunda kalmıştır. Çünkü her şeyden önce bu tarihlerde Bopal, İngilizlere bağlı yarı müstakil bir devlettir. Cihan Begüm'ün bunun aksine davranması pek mümkün görünmemektedir. Ayrıca o dönemde Hindistan'da Osmanlı ve halifelik üzerine yapılan tartışmalarda Cihan Begüm, İngilizlerden yana olan Aligarh Ekolü’ne yakındır. Kurucusu olduğu üniversiteden ortaya çıkan bu görüşü benimsemesi akla yatkındır. Böylece mecbur olduğu siyasî ortamla birlikte bu ekol, İslam halifesine karşı İngilizleri destekleme konusunda dinî ve hukukî bir zemin sağlamıştır. 


\section{Kaynakça}

[1] BOA, Bâb-1 Âlî Evrak Odası (BEO.): 2267/169983, 2949/221151, 4072/305349, 4083/306224, 4159/311859, 4163/312188.

[2] BOA, Dahiliye Tahrirat Kalemi (DH.EUM.THR.): 80/66, 78/30.

[3] BOA, Hariciye Nezareti Londra Sefareti (HR.SFR.3...): 528/69, 639/35, 639/41.

[4] BOA, Hariciye Nezareti Siyasi (HR.SYS..): 1234/70, 2019/4.

[5] BOA, Hariciye Nezareti Tercüme Odası (HR.TO..): 542/24

[6] BOA, İrade Mabeyn-i Hümayun (İ..MBH.): 11/104, 11/95.

[7] BOA, İrade Meclis-i Vala (İ.MVL...): 340/14687.

[8] BOA, Meclis-i Vükela Mazbataları (MV.): 234/170

[9] BOA, Sadaret Meclis-i Vala Evrakı (A.\}MKT.MVL.): 75/33.

[10]BOA, Sadaret Mektubi Mühimme Kalemi Evrakı (A.\}MKT.MHM..): 282/39.

[11]BOA, Y1ldız Hususi Maruzat (Y.A.HUS..): 468/10, 472/54, 460/129, 460/96, 459/79.

[12]Cezar, Mustafa(1963), “Osmanlı Devrinde İstanbul Yapılarında Tahribat Yapan Yangınlar ve Tabii Âfetler”, Türk Sanat Tarihi Araştırmalart ve Incelemeleri I, İstanbul. (327-414)

[13]Çetinsaya, Gökhan(1988), II. Abdülhamit Döneminin İlk Yıllarında “íslâm Birliği”" Hareketi (1876-1878), Ankara. (AÜ Sosyal Bilimler Enstitüsü Basılmamış Yükseklisans Tezi).

[14]Eraslan, Cezmi(1992), II. Abdülhamit ve İslâm Birliği, Ötüken Yay., İstanbul.

[15]Eren, Cüneyt ve Yılmaz, Nurullah(2002), "Hindistan Bhopal Emiri Ve Müfessir Siddık Hasan Han'ın Osmanlı Devleti İle IIlişkisı”, A. Ü. Türkiyat Araştırmaları Enstitüsü Dergisi, S. 19. (233-238)

[16]https://tr.pinterest.com/pin/688417493023059652/visual-search/ (Erişim Tarihi 04.11.2019)

[17]Hurley, S. Lambert(1998a), Contesting Seclusion: The Political Emergence of Muslim Women in Bhopal, 1901-1930, London. (SOAS Yayınlanmamış Doktora Tezi).

[18]Hurley, S. Lambert(1998b), “Out of India: The Journeys of the Begam of Bhopal, 1901 1930”, Women's Studies'International Forum, 21:3, June. (263-276)

[19]Hurley, S. Lambert(2003), "Princes, paramountcy and the politics of Muslim identity: the Begam of Bhopal on the Indian national stage, 1901-1926”, South Asia: Journal of South Asian Studies, 26 (2).(169195)

[20]Islam, Tuhina(2014), "Social and Educational Reforms of Nawab Sultan Jahan Begum”, The International Journal Of Humanities \& Social Studies, Vol 2 Issue 8, August. (47-52) 
Bopal Nevvabı Sultan Cihan Begüm'ün İstanbul Ziyareti ve Osmanlı'ya Gönderdiği Yardımlar/ Berna KORUCU $\underline{\text { ÜÇÜNCÜ }}$

[21]İskender Begüm(1870), A Prilgrimage To Mecca, Çev. W. Osborne, London.

[22]İzgöer, Ahmet Zeki(2015), “1911-1913 (1329-1331) Tarihli Osmanlı Hilâl-i Ahmer Sâlnâmesine Göre Balkan Savaşları Sırasında Hint Müslüman Halkının Osmanlı'ya Yardımları”, Journal of History and Future, I/1, Aralik. (99-171)

[23]Konukçu, Enver(1992), “Bopal”, Türkiye Diyanet Vakfi İslam Ansiklopedisi, C. 6, İstanbul.

[24]Layd Glover(1927), Great Queens Famous Women Rulers of The East, London.

[25]Öke, Mim Kemal(2005), Hilâfet Hareketleri, İrfan Yay., İstanbul.

[26]Özcan, Azmi(1997), Pan-İslamizm-Osmanl Devleti, Hindistan Müslümanları ve İniltere (1877-1924), Ankara.

[27]Özcan, Azmi(2007), 'Nevvâb”, Türkiye Diyanet Vakfi İslam Ansiklopedisi, C.33, İstanbul.

[28]Özcan, Azmi(2010), “Şah Cihan Begüm”, Türkiye Diyanet Vakfi İslam Ansiklopedisi, C.38, İstanbul.

[29]Preckel, Claudia(2000), Begums Of Bhopal, New Delhi.

[30]Sebilü'r-Reşad, 27 Şubat 1329, 17 Temmuz 1329.

[31]Sultan Cihan Begüm(1913), The Story Of Pilgrimage To Hijaz, Calcutta.

[32]Sultan Cihan Begüm(1918), Hayat-i Qudsia: Life Of Nawab Gauhar Begam Alias The Nawab Begam Qudsia Begum Of Bhopal, Çev. W. S. Davis, London.

[33]Sultan Cihan Begüm(1922), Al Hijab or Why Purdah is Necessary, Kalküta.

[34]Sultan Cihan Begüm(1926), Hayat- Shahjehani: Life Of Her Highness The Late Nawab Shahjehan Begum Oh Bhopal, Çev. B. Ghosal, Bombay 1926.

[35]Sultan Cihan Begüm(1927), An Account Of My Life: Gohur-i Ikbal, Vol 1, Çev. C H. Payne, London 1912. Vol. 2 Çev. Abdus Samad Khan, Bombay 1922. Vol. 3 Çev.C. H. Payne, Bombay 1927.

[36]Şah Cihan Begüm (1876), Taj ul -lkbal Tarikh Bhopal; or The History Of Bhopal, Çev. H. C. Barstow, Calcutta.

[37]Şahbanu Begüm(1914), A Trip To Europe, çev. G. Baksh, Kalküta.

[38]Şerif’ül-Hasan(1965), “1876-1877 Türk-Rus Savaşı’nda Pakistan’ın Türkler’e Yardımı”, Hayat Tarih Mecmuas1, II/11, Aralik. (21)

[39]Tellioğlu, Ömer(2015), "Hindistan Müslümanlarının Osmanlı Devleti'ne Bağlllğının Sembolü: Trablusgarb ve Balkan Savaşları Sırasında Gönderilen Yardımlar", Tarih Okulu Dergisi, S. 24, Aralık. (791-808) 
ISSN: $2667-4432$

Journal of Universal History Studies (JUHIS) • 2(2) • December • 2019 • pp. 251-268

[40]The Evening News, 31 Ağustos 1911.

[41]The Guardian, 31 July 1911, 1 Ağustos 1911.

[42]The Observe, 16 July 1911.

[43]The Times, 07.08.1911.

[44]Türkiye Büyük Millet Meclisi, Zabit Cerideleri, 13.09.1336, İ. 64, C. 3, s. 128.

[45]Uslu, Recep(1993), “Cihan Begüm”, Türkiye Diyanet Vakfi İslam Ansiklopedisi, ,C. 7, İstanbul.

[46]Uşaklıgil, Halit Ziya(2012), Saray ve Ötesi, Yay. Haz. N. Ö. Akın, İstanbul.

[47]Üçok, Bahriye(1972), "Hindistan'da Bopal Devleti'nde Bir Naibe ve 3 Kadın Hükümdar", TTK Tebliğler VII. (446-450)

[48]Yeni İkdam, 17 Temmuz 1327, 18 Temmuz 1327, 13 Ağustos 1327, 14 Ağustos 1327, 15 Ağustos 1327. 


\section{Ekler}

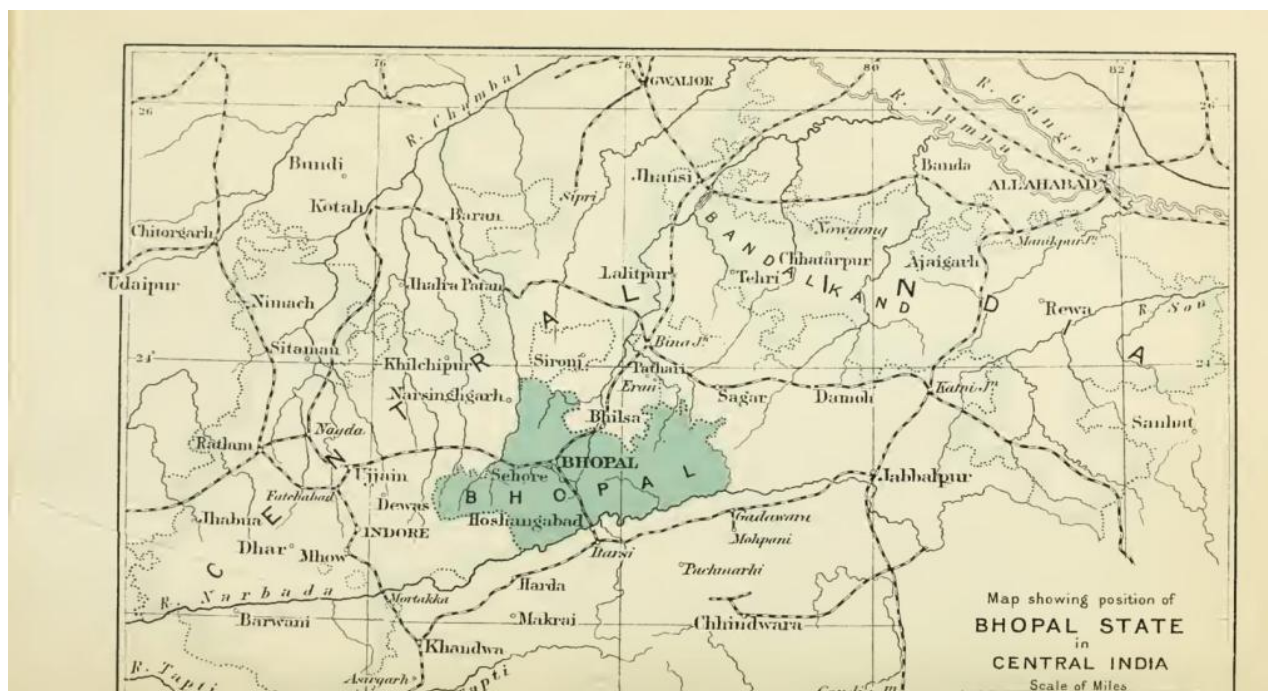

Ek 1: Bopal Nevvablığı Haritası (Sultan Cihan Begüm, An Account Of My Life: Gohur-i lkbal, Vol 1, Çev. C H. Payne, London 1912.)

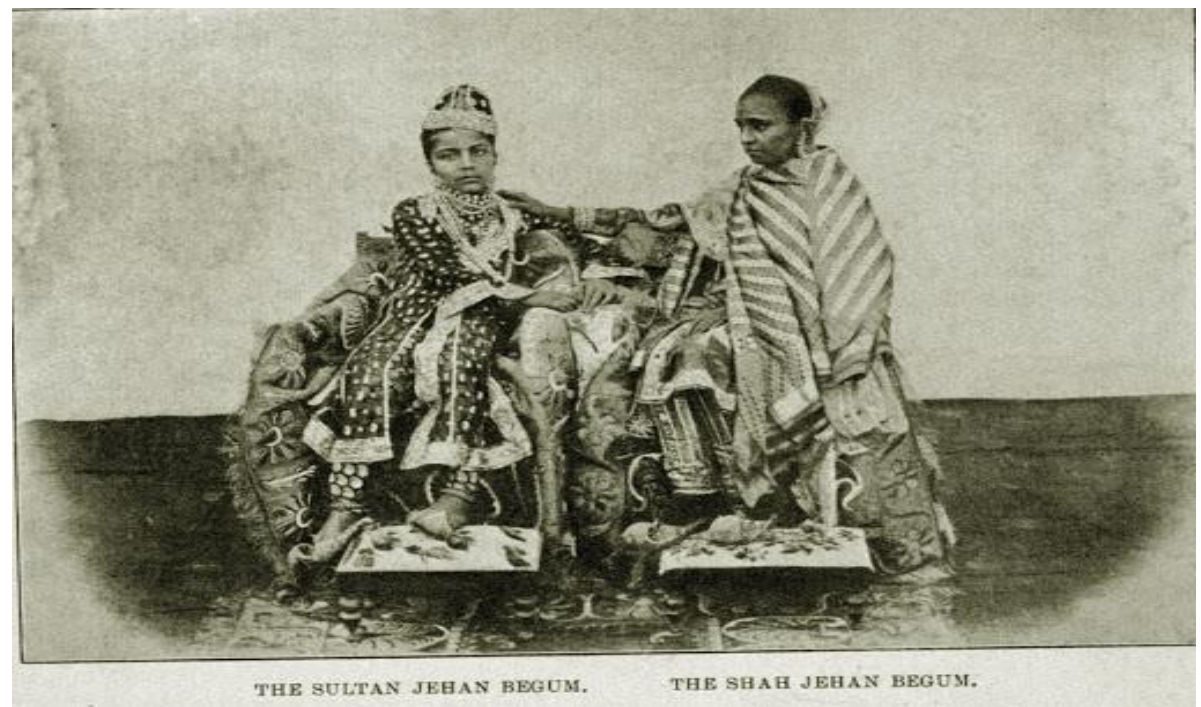

Ek 2: Sultan Cihan Begüm ve annesi Şah Cihan Begüm (Sultan Cihan Begüm, An Account Of My Life: Gohur-i Ikbal, Vol 1, Çev. CH. Payne, London 1912, s. 28) 


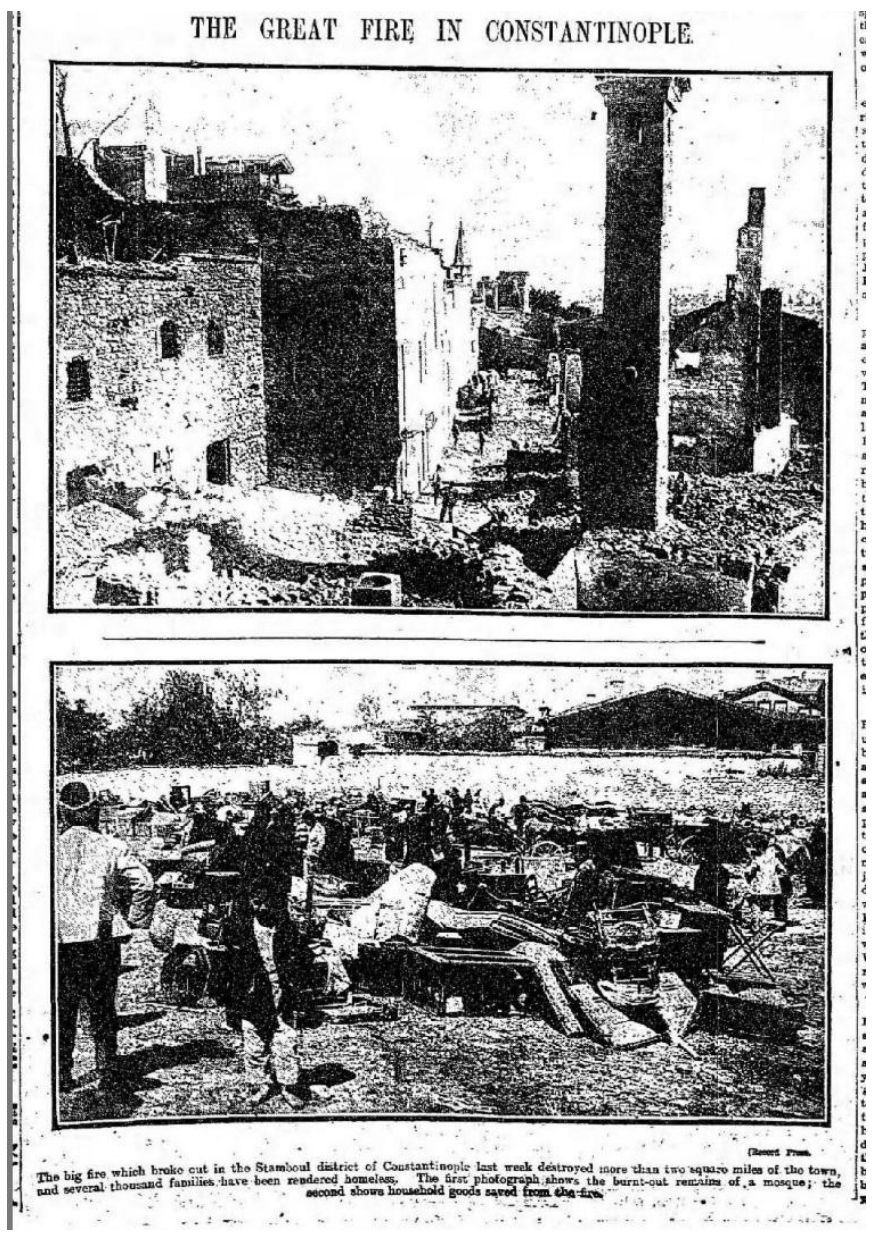

Ek 3; İstanbul Yanginı, The Guardian, 1 Ağustos 1911, s. 7. 


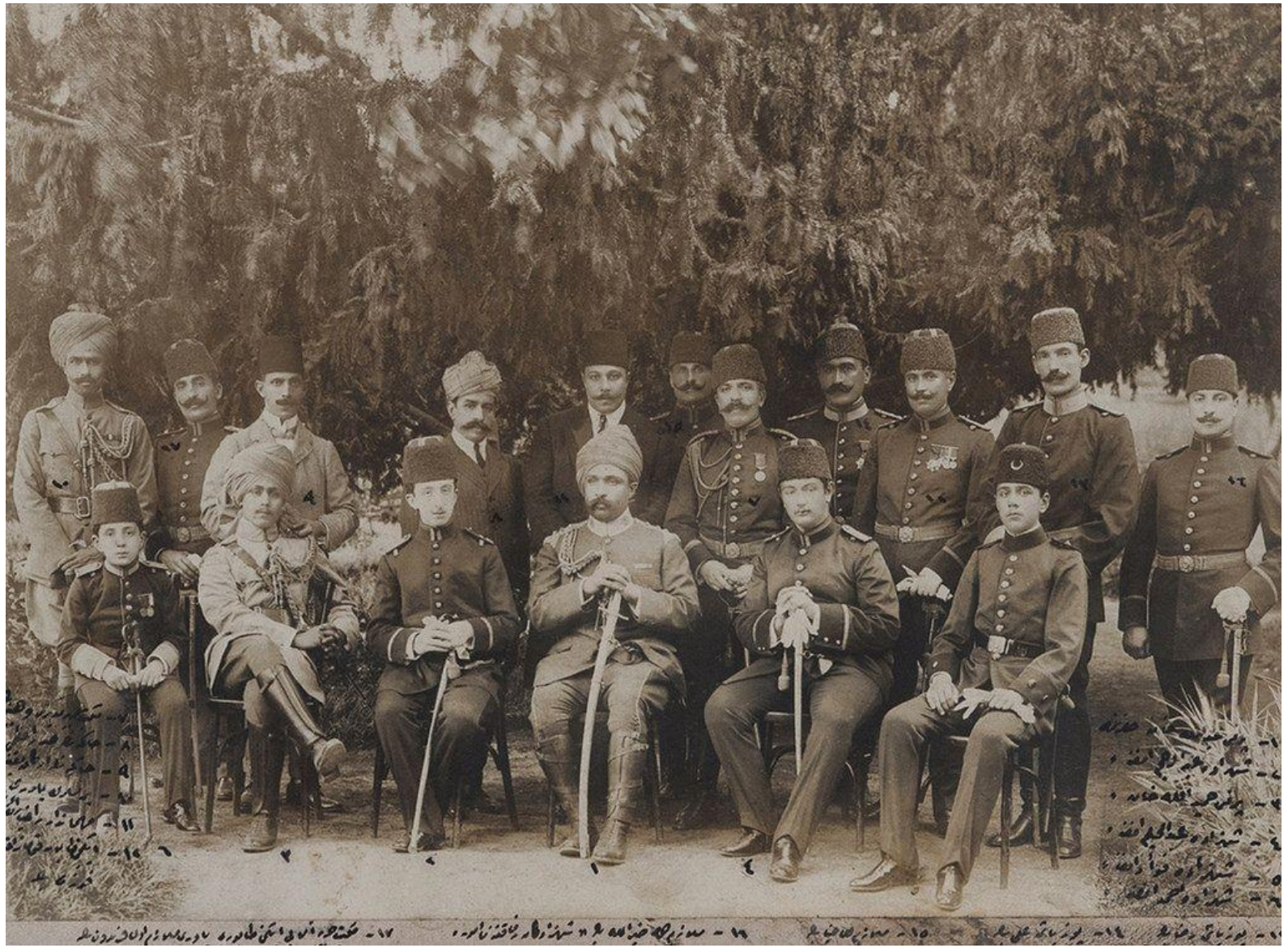

Ek 4; Cihan Begüm'ün oğulları Ubeydullah Han ile Hamidullah Han'ın Mekteb-i Harbiye ziyareti (önde sağdan üçüncü Ubeydullah Han, beşinci Hamidullah Han) https://tr.pinterest.com/pin/688417493023059652/visual-search/ (Erişim Tarihi 04.11.2019)

2-Şehzade Abdürrahim Efendi (Sultan Abdülhamit'in oğlu)

4-Şehzade Abdülhalim Efendi, Selim Süleyman Efendi’nin oğlu (Sultan Abdülmecid'in Torunu)

5- Şehzade Fuad, (V. Murad'in torunu)

6-Şehzade Ahmet Efendi 